\title{
Binding and Internalization of Herpes Simplex Virus-Antibody Complexes by Polymorphonuclear Leukocytes
}

\author{
Jerry W. Smith, James R. Jachimowicz, and Eve L. Bingham \\ Department of Ophthalmology, University of Michigan, Ann Arbor, Michigan \\ (J.W.S., E.L.B.); Difco Laboratories, Detroit, Michigan (J.W.S.); Department of \\ Microbiology and Immunology, Louisiana State University, New Orleans, \\ Louisiana (J.R.J.)
}

\begin{abstract}
We studied the interactions between rabbit polymorphonuclear leukocytes (PMN) and the RE strain of herpes simplex virus type 1 (HSV-1) to determine better the role of inflammatory cells in herpetic stromal keratitis. PMN were found to be nonpermissive for HSV replication and were unable to bind virus in the absence of antibody. However, PMN did bind and internalize HSV-antibody complexes in vitro as was demonstrated visually by electron microscopic studies and quantitatively by measurement of activity associated with radiolabeled HSV-antibody complexes. Virus used for immune complex formation was labeled with either ${ }^{125}$ Iodine or ${ }^{35} \mathrm{~S}$-methionine. In some experiments, anti-HSV IgG used for immune complex formation was labeled with ${ }^{125}$ Iodine before incubation with virus. Use of all three radiolabeling approaches resulted in the same general pattern of binding, indicating a requirement for both antibody and virus for interaction with PMN. The activity associated with PMN was increased by preincubation with complement. The results suggest an active role for PMN in controlling HSV infection through their ability to bind and ingest virus-antibody complexes.
\end{abstract}

Key words: herpes simplex virus type 1 , polymorphonuclear leukocyte, antigen-antibody complex

\section{INTRODUCTION}

Traditionally, the most important cells involved in antiviral immunity have been thought to be those comprising the lymphocyte-macrophage defense system. Although polymorphonuclear leukocytes (PMN) have been shown to function as primary effector cells in acute inflammatory responses to bacterial and mycotic infections, there is increasing evidence to suggest PMN play an important role in antiviral defense.

PMN have been observed in the inflammatory infiltrates in specific infections; for example, the cerebrospinal fluid of children with viral meningitis [Feigin and

Accepted for publication April 21, 1986.

Address reprint requests to Dr. J.W. Smith, Department of Ophthalmology, Kellogg Eye Center, 990 Wall St., Ann Arbor, MI 48105.

(C) 1986 Alan R. Liss, Inc. 
Shakelford, 1973] and the cutaneous lesions of varicella zoster infections [Stevens et al, 1975]. In herpetic stromal keratitis, a disease characterized by corneal opacity and scarring, an infiltrate consisting mainly of PMN and macrophages persists in the limbus and later the cornea for 4-5 days postinfection [Metcalf and Reichert, 1979].

A possible role for PMN in lower respiratory tract infections caused by respiratory syncytial virus (RSV) has been suggested by demonstrating in vitro activation of oxidative and arachidonic acid metabolism of PMN with RSV immune complexes [Kaul et al, 1981; Faden et al, 1983].

Although interactions that occur between host phagocytes and herpes simplex virus (HSV) during infection have not been extensively investigated, it has been assumed that the known mechanisms of antimicrobial immunity mediated by PMN participate in the activation and clearance of virus and virus-antibody complexes [Notkins et al, 1970; Theofilopoulos and Dixon, 1979; Sedlacek, 1980]. Previous studies in our laboratory, using chemiluminescence as an indicator of membrane perturbation and/or phagocytosis, suggest that PMN exert anti-HSV activity in the presence of specific antibody, but the virus alone has no effect [Bingham et al, 1985]. In an effort to clarify further the interactions between PMN and HSV in ocular infection, we studied the ability of PMN to mediate clearance of virus and virusantibody complexes. The rabbit was used for our studies because the clinical disease in this model parallels the sequence of disease in human herpes keratitis [MeyersElliot et al, 1983]. The parameters addressed were: (1) the permissiveness of PMN to HSV replication, (2) the ability of PMN to bind and ingest HSV, and (3) the ability of PMN to bind and phagocytize HSV-antibody complexes.

\section{MATERIALS AND METHODS Preparation of PMN}

Blood was collected from adult New Zealand white rabbits into a syringe containing heparin ( 20 units $/ \mathrm{ml}$ blood). PMN were separated from whole blood by modification of the method described by Boyum [1968]. Briefly, $10 \mathrm{ml}$ of heparinized blood was diluted 1:4 with Hanks balanced salt solution (HBSS), layered on a FicollHypaque gradient, and centrifuged for $40 \mathrm{~min}$ at $400 \mathrm{~g}$. The resulting erythrocytePMN pellet was resuspended in $20 \mathrm{ml}$ of autologous plasma and $8 \mathrm{ml}$ of a $4.5 \%$ Dextran T-500 solution and incubated for $60 \mathrm{~min}$ at $37^{\circ} \mathrm{C}$.

Following incubation, the PMN-rich supernatant was collected and spun for 10 min at $300 \mathrm{~g}$. Residual erythrocytes were lysed with ACK buffer $\left(30 \mathrm{mM} \mathrm{NH}_{4} \mathrm{Cl}, 2\right.$ $\mathrm{mM} \mathrm{KHCO}, 0.02 \mathrm{mM}$ disodium EDTA). PMN purity was greater than $95 \%$ as assessed by Wrights stain and PMN viability exceeded $90 \%$ as determined by trypan blue exclusion.

\section{Preparation of Virus}

The RE strain of HSV-1 was used. This strain was originally isolated from a human corneal lesion and has been used in studies of herpetic stromal disease in rabbits without a high incidence of mortality from encephalitis. It produces a spectrum of disease in rabbits comparable to that seen in humans [Irvine and Kimura, 1967; Metcalf et al, 1976; Wander et al, 1980].

The RE strain was grown in SIRC (Staaten Serum Institut Rabbit Cornea) monolayers with minimal essential medium (MEM) and 5\% fetal calf serum (FCS) at 
$37^{\circ} \mathrm{C}$. When cytopathological changes involved $100 \%$ of the monolayer, culture fluid from infected cells was clarified by two cycles of low speed centrifugation (500 g for $15 \mathrm{~min}$ ). The resulting supernatant was precipitated with polyethylene glycol (PEG) as described by Powell and Watson [1975] to obtain an enriched population of enveloped virus.

After an overnight incubation, the HSV precipitate was layered over a continuous $20-60 \%$ sucrose gradient and centrifuged at $85,000 \mathrm{~g}$ for $60 \mathrm{~min}$. The virus band was collected, repelleted, rebanded on a sucrose gradient, and resuspended in MEM supplemented with $2 \% \mathrm{FCS}$ and stored at $-70^{\circ} \mathrm{C}$. The PEG-purified HSV preparation had a titer of $8 \times 10^{7}$ plaque forming units $(\mathrm{PFU}) / \mathrm{ml}$ in Vero cells.

\section{Virus Replication in PMN}

Peripheral blood PMN from normal rabbits were suspended in RPMI-1640 medium with $20 \%$ rabbit serum and seeded into 24 -well tissue culture plates $\left(5 \times 10^{5}\right.$ $\mathrm{PMN} /$ well). After $60 \mathrm{~min}$ at $37^{\circ} \mathrm{C}$, PMN cultures were incubated with HSV until harvest or exposed to virus $2 \mathrm{hr}$, washed, and overlaid with fresh medium. Culture supernatants were harvested at various time intervals up to $96 \mathrm{hr}$. Fluids were clarified by centrifugation ( $500 \mathrm{~g}$ for $10 \mathrm{~min}$ ) and quantitated for plaque forming units on Vero cell monolayers using $1 \%$ agarose in MEM as the overlay medium.

\section{Virus Adsorption to PMN}

Both rabbit peripheral blood PMN and Vero cells were adjusted to a concentration of $2 \times 10^{6}$ cells $/ \mathrm{ml}$ in RPMI-1640 supplemented with $10 \%$ rabbit serum. We added $0.5 \mathrm{ml}$ of cells or medium alone to wells of a 24 -well plastic tissue culture plate and mixed with $0.1 \mathrm{ml}$ of $\mathrm{HSV}$ at $22^{\circ} \mathrm{C}$. Virus was diluted to achieve input multiplicities of infection (MOI) of 10 and 1 . At designated times after addition of virus $(5,15,30$, and $60 \mathrm{~min})$ culture fluid was harvested, clarified by centrifugation ( $500 \mathrm{~g}$ for $10 \mathrm{~min}$ ), and quantitated by plaque assay in Vero cells.

\section{Purification of $\lg \mathrm{G}$}

Antiserum to the RE strain of HSV-1 was produced in New Zealand white rabbits weighing $2-3 \mathrm{~kg}$. Each eye was injected intrastromally with $0.02 \mathrm{ml}$ of virus preparation containing $10^{6} \mathrm{PFU}$.

At 28 days postinfection, animals were exsanguinated and the blood allowed to clot at room temperature. The serum was separated by one cycle of centrifugation and then heated for $30 \mathrm{~min}$ at $56^{\circ} \mathrm{C}$ to inactivate complement.

IgG was precipitated from immune serum with a neutralization titer of 1024 by the addition of ammonium sulfate and then separated from other charged serum proteins by ion exchange chromatography on DEAE cellulose [Garvey et al, 1977]. Peak protein fractions from the column were pooled and concentrated on a PM-10 membrane (Amicon Corp., Lexington, MA). The protein content of purified IgG was determined by absorbance at $280 \mathrm{~nm}$ and purity analysis done by Ouchterlony immunodiffusion.

\section{Radiolabeling of Purified HSV and IgG}

Purified HSV was radiolabeled with ${ }^{125}$ Iodine (New England Nuclear, Boston, MA) either by the lactoperoxidase method described by Fenger et al [1978] or through 
metabolic incorporation of the amino acid ${ }^{35} \mathrm{~S}$-methionine [Eberle and Courtney, 1980].

Purified IgG was radiolabeled by the chloramine-T method of McConahey and Dixon [1966] and by the lactoperoxidase technique of Marchalonis [1969], modified by Kozel and McGaw [1979].

\section{Preparation of Virus-Antibody Complexes}

Purified radioiodinated HSV $(1.3 \mathrm{mg} / \mathrm{ml}$ protein) was combined in equal parts with either a 1:10 dilution of rabbit antiserum to HSV or commercial rabbit serum that showed no antibody to HSV. Following a 30 -min incubation at $37^{\circ} \mathrm{C}$, virusantibody complexes and free virus were pelleted by centrifugation $(85,000 \mathrm{~g}$ for 60 min), washed twice with MEM plus $2 \% \mathrm{FCS}$, and stored at $-70^{\circ} \mathrm{C}$. Immune complexes containing ${ }^{35} \mathrm{~S}-\mathrm{HSV}$ were made, washed, and stored in a similar manner.

Radioiodinated IgG $(1 \mathrm{mg} / \mathrm{ml})$ was prepared from rabbit antiserum to $\mathrm{HSV}$ and combined in equal volumes with purified virus. The mixture was incubated for 30 min at $37^{\circ} \mathrm{C}$ in a shaking waterbath and then centrifuged at $1000 \mathrm{~g}$ for $30 \mathrm{~min}$ to sediment the insoluble complexes. The complexes were washed twice, resuspended in $\mathrm{MEM}$ plus $2 \% \mathrm{FCS}$, and stored at $-70^{\circ} \mathrm{C}$.

\section{Immune Complex Binding Assay}

The uptake of radiolabeled complexes by rabbit PMN was measured by a modification of the coverslip assay of Smith and Rommel [1977]. In this assay system, $12 \mathrm{~mm}$ round \#1 thickness coverslips were cleaned with acetone and placed in $16 \mathrm{~mm}$ wells of a 24-well tissue culture plate. PMN in RPMI-1640 supplemented with $20 \%$ normal rabbit serum were seeded onto the coverslip $\left(5 \times 10^{5} \mathrm{PMN} /\right.$ coverslip $)$ and allowed to adhere for $1 \mathrm{hr}$ at $37^{\circ} \mathrm{C}$ in a $5 \% \mathrm{CO}_{2}$ atmosphere. Control (blank) coverslips were treated with medium plus rabbit serum. Following incubation, each coverslip was washed with medium to elute nonadherent cells and serum components.

We added $50 \mu \mathrm{l}$ of radiolabeled complexes to each coverslip. After a 10-min incubation at $37^{\circ} \mathrm{C}$, the coverslips were removed from wells, washed four times with medium, drained dry with a tissue, and inserted into a bio-vial (Beckman). Iodinated samples were counted on a Biogamma counter (Beckman) to quantitate coverslip associated radioactivity. Quantitation of ${ }^{35} \mathrm{~S}$-radioactivity was accomplished by tissue solubilization and liquid scintillation spectrometry as described by Smith et al [1979].

\section{Electron Microscopy}

Complexes formed by combining PEG concentrated HSV and ammonium sulfate precipitated IgG were incubated with rabbit $P M N$ for $5 \mathrm{~min}$ at $37^{\circ} \mathrm{C}$. In preparation for thin sectioning, PMN were washed twice with Tyrode's solution ( $\mathrm{pH}$ 7.2), fixed in $1 \%$ glutaraldehyde, postfixed in osmium tetroxide, dehydrated in ethanol, and embedded in epoxy resin (Araldite). Thin sections were stained with uranyl acetate and lead citrate ( $\mathrm{pH} \mathrm{7.0)}$ and examined in a Phillips 201 electron microscope.

\section{RESULTS}

\section{Permissiveness of Rabbit Peripheral Blood PMN to HSV Replication}

Studies were done to determine if the interaction between HSV and PMN results in viral replication. The findings in Figure 1 indicate that no detectable replication of 


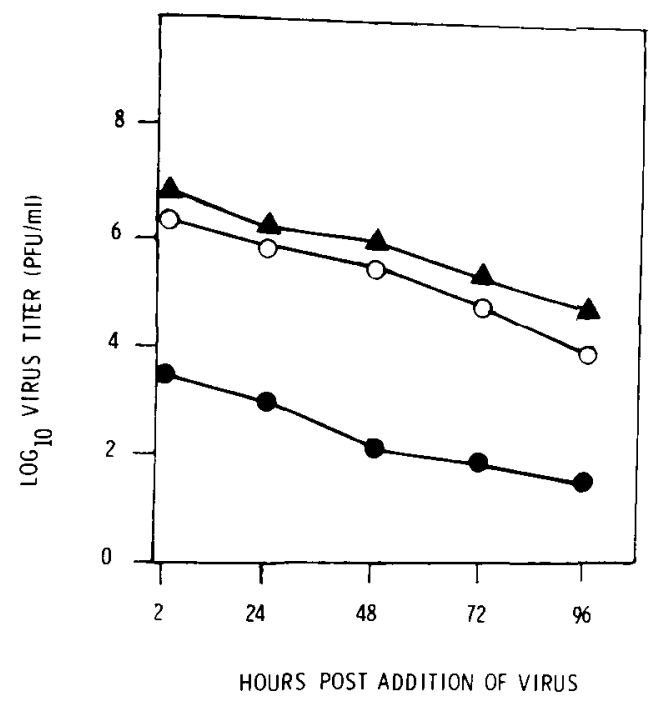

Fig. 1. Replication of HSV in PMN. PMN from peripheral blood of normal rabbits were allowed to adhere to bottoms of 24-well plastic tissue culture plates $\left(5 \times 10^{5}\right.$ cells/well $)$ before exposure to infectious virus (MOI of 100). Tissue culture fluid was harvested at various times after addition of virus. The titer of infectious HSV was determined by plaque assay under agarose on Vero cell monolayers. Results are expressed as the mean of triplicate cultures. Symbols: $\triangle$ medium + HSV; PMN + HSV incubated for $2 \mathrm{hr}$ at $37^{\circ} \mathrm{C}$ and washed to remove HSV inoculum; O PMN + HSV incubated together at $37^{\circ} \mathrm{C}$.

HSV occurs in rabbit PMN. Cultures exposed to infectious virus for $2 \mathrm{hr}$ or longer showed no increase in virus yield. Slight decreases in virus titer were observed in all samples examined beyond $2 \mathrm{hr}$. Both PMN exposed to virus and that incubated with medium alone exhibited similar patterns of loss of infectivity. Electron microscopy revealed no evidence of permissive or abortive infection in PMN examined 24-48 hr after addition of HSV (data not shown).

\section{Binding of HSV to Rabbit Peripheral Blood PMN}

To determine if rabbit PMN bound or absorbed HSV, experiments were performed in which infectious virus was exposed to PMN in culture. Supernatant fluids were examined for virus at various time intervals. Results shown in Figure 2 indicate no adsorption or binding of HSV to PMN. Supernatant fluids contained the same amount of infectious virus before and after incubation with PMN for both MOI's examined, 10 and 1 . Vero cell monolayers served as positive binding controls. Decreases in virus titer were observed in supernatants from Vero cells as early as 5 min after exposure to HSV.

\section{Binding of HSV-Antibody Complexes to PMN Using Radiolabeled Virus Preparations}

In an effort to determine if virus-antibody complexes interact with PMN, experiments were performed in which enveloped HSV, either externally labeled with ${ }^{125}$ Iodine or metabolically labeled with ${ }^{35} \mathrm{~S}$-methionine, was exposed to immune serum and the resulting complexes were assayed for binding. Results in Table I show that enveloped ${ }^{125} \mathrm{I}-\mathrm{HSV}$ incubated with normal rabbit serum was bound to PMN at 


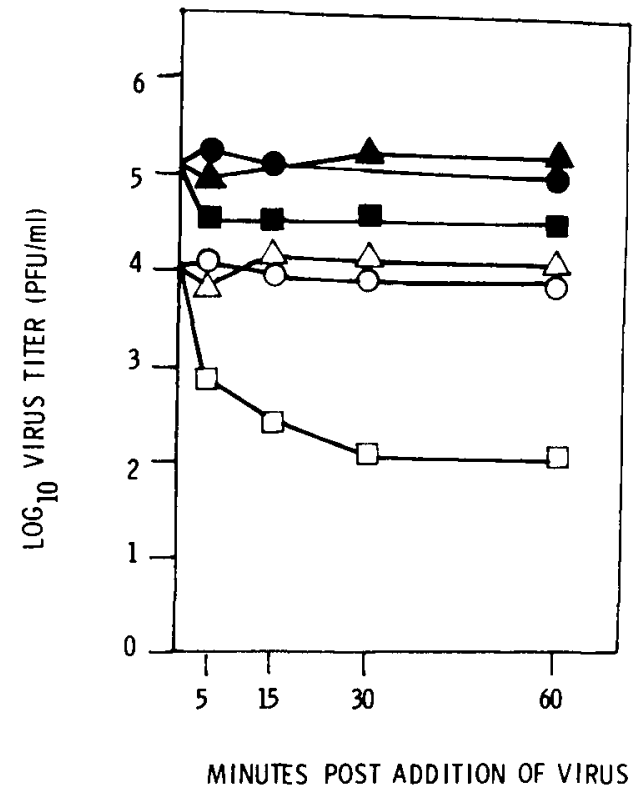

Fig. 2. Binding of HSV to PMN. Infectious HSV was added to suspensions of either $2 \times 10^{6}$ rabbit PMN or $2 \times 10^{6}$ Vero cells at MOI's of 10 and 1. The cultures were continuously agitated and at designated time intervals aliquots were collected. Culture fluids were clarified of cells by centrifugation at $500 \mu \mathrm{g}$ and screened for reduction in HSV titer by plaque assay under agarose on Vero cells. Results are expressed as mean values of triplicate samples. MOI of 10: $\Delta$ medium $+\mathrm{HSV}$; PMN + HSV; $\square$ Vero + HSV. MOI of 1: $\triangle$ medium + HSV; $\bigcirc$ PMN + HSV; $\square$ Vero + HSV.

TABLE I. Binding of Virus-Antibody Complexes to PMN Using Radiolabeled HSV Preparations

\begin{tabular}{|c|c|c|}
\hline \multicolumn{2}{|c|}{ Reaction mixture } & \multirow{2}{*}{$\begin{array}{l}\text { Activity } \\
(\mathrm{CPM})^{\mathrm{a}}\end{array}$} \\
\hline Cells & Complex & \\
\hline None & ${ }^{125} \mathrm{I}-\mathrm{HSV}+\mathrm{NRS}^{\mathrm{b}}$ & $980 \pm 82$ \\
\hline None & ${ }^{125} \mathrm{I}-\mathrm{HSV}+\mathrm{Ab}$ & $1446 \pm 162$ \\
\hline PMN & ${ }^{125} \mathrm{I}-\mathrm{HSV}+\mathrm{NRS}$ & $4591 \pm 171$ \\
\hline PMN & ${ }^{125} \mathrm{I}-\mathrm{HSV}+\mathrm{Ab}$ & $14942 \pm 1001$ \\
\hline None & ${ }^{35} \mathrm{~S}-\mathrm{HSV}+\mathrm{NRS}$ & $105 \pm 10$ \\
\hline None & ${ }^{35} \mathrm{~S}-\mathrm{HSV}+\mathrm{Ab}$ & $602 \pm 54$ \\
\hline PMN & ${ }^{35} \mathrm{~S}-\mathrm{HSV}+\mathrm{NRS}$ & $2750 \pm 244$ \\
\hline PMN & ${ }^{35} \mathrm{~S}-\mathrm{HSV}+\mathrm{Ab}$ & $6516 \pm 595$ \\
\hline
\end{tabular}

${ }^{\text {a }}$ Results represent the mean of sextuplicate coverslips \pm SEM.

${ }^{b}$ NRS, normal rabbit serum.

greater than fourfold the amount of activity associated with control coverslips. Addition of complexes of ${ }^{125} \mathrm{I}-\mathrm{HSV}$ and HSV specific antibody produced activity tenfold greater than blank coverslips and threefold greater than that associated with PMN and virus exposed to nonimmune serum.

The same pattern of response was seen when ${ }^{35} \mathrm{~S}-\mathrm{HSV}$ was substituted for ${ }^{125} \mathrm{I}-$ HSV in immune complexes. Approximately the same ratios of activity were observed. Immune complexes formed using ${ }^{35} \mathrm{~S}-\mathrm{HSV}$ antibody demonstrated the highest activity associated with PMN. 


\section{Binding of Virus-Antibody Complexes to PMN Using Radiolabeled Anti-HSV IgG}

The results of experiments using complexes comprised of ${ }^{125} \mathrm{I}-\mathrm{IgG}$ and $\mathrm{HSV}$ to demonstrate binding to PMN are shown in Table II. With nonspecific binding controls $\left({ }^{125} \mathrm{I}\right.$-IgG and supernatant from uninfected SIRC cells), no increase in ${ }^{125} \mathrm{I}$-IgG activity associated with PMN was detected above background binding levels. However, when complexes of ${ }^{125} \mathrm{I}-\mathrm{IgG}$ and unlabeled HSV were combined with PMN, a tenfold increase in activity was observed.

\section{Effect of Complement on the Binding of Virus-Antibody Complexes to PMN}

To examine the effect of complement, experiments were performed in which either heat inactivated or native guinea pig complement was added to immune complexes. Incubation of immune complexes with native guinea pig complement produced an approximate twofold increase in activity bound to PMN over complexes incubated with heat inactivated complement (Table III). Controls showed an approximate fourfold increase in activity of ${ }^{125} \mathrm{I}-\mathrm{HSV}$ and antibody complexes associated with PMN compared to background coverslips.

\section{Internalization of HSV-Antibody Complexes by PMN}

To determine whether the interactions between PMN and HSV-antibody complexes resulted in internalization by phagocytosis, we performed experiments utilizing

TABLE II. Binding of Virus-Antibody Complexes to PMN Using Radiolabeled Anti-HSV IgG

\begin{tabular}{lcc} 
Cells & \multicolumn{1}{c}{ Reaction mixture } & $\begin{array}{r}\text { Complex } \\
\text { Activity } \\
(\text { CPM })^{\mathrm{a}}\end{array}$ \\
\hline None & ${ }^{125} \mathrm{I}-\mathrm{IgG}+$ medium $^{\mathrm{b}}$ & $274 \pm 14$ \\
None & ${ }^{125} \mathrm{I}-\mathrm{IgG}+\mathrm{HSV}^{\mathrm{c}}$ & $339 \pm 61$ \\
PMN & ${ }^{125} \mathrm{I}-\mathrm{IgG}+$ medium & $342 \pm 9$ \\
PMN & ${ }^{125} \mathrm{I}$-IgG + HSV & $3419 \pm 286$ \\
\hline
\end{tabular}

${ }^{\text {a }}$ Results represent the mean of triplicate coverslips \pm SEM.

${ }^{b}$ Antibody incubated with supernatant from uninfected SIRC cultures $\left(30 \mathrm{~min}\right.$ at $37^{\circ} \mathrm{C}$ ) and pelleted by ultracentrifugation $(85,000 \mathrm{~g}$ for $60 \mathrm{~min})$.

'Insoluble immune complexes pelleted by low speed centrifugation (1,000 $\mathrm{g}$ for $30 \mathrm{~min})$ and washed prior to use.

TABLE III. Effect of Complement on the Binding of Virus-Antibody Complexes to PMN

\begin{tabular}{lcc}
\hline & Reaction mixture & \multicolumn{1}{c}{$\begin{array}{c}\text { Activity } \\
(\mathrm{CPM})^{\mathrm{a}}\end{array}$} \\
\hline Cells & \multicolumn{1}{c}{ Complex } & $684 \pm 101$ \\
None & ${ }^{125} \mathrm{I}-\mathrm{HSV}+\mathrm{Ab}+\Delta \mathrm{C}^{\mathrm{b}}$ & $1166 \pm 95$ \\
None & ${ }^{125} \mathrm{I}-\mathrm{HSV}+\mathrm{Ab}+\mathrm{C}^{\mathrm{c}}$ & $2850 \pm 230$ \\
PMN & ${ }^{125} \mathrm{I}-\mathrm{HSV}+\mathrm{Ab}+\Delta \mathrm{C}$ & $4492 \pm 304$ \\
PMN & ${ }^{125} \mathrm{I}-\mathrm{HSV}+\mathrm{Ab}+\mathrm{C}$ & \\
\hline
\end{tabular}

${ }^{a}$ Results represent the mean of quadruplicate coverslips \pm SEM.

${ }^{\mathrm{b}} \mathrm{Complexes}$ incubated for $30 \mathrm{~min}$ at $37^{\circ} \mathrm{C}$ with an equal volume of a 1:10 dilution of heat-inactivated guinea pig complement. ${ }^{c} \mathrm{Complexes}$ incubated for $30 \mathrm{~min}$ at $37^{\circ} \mathrm{C}$ with an equal volume of a 1:10 dilution of guinea pig complement. 
electron microscopy. Figure 3 shows the results of incubating virus-antibody complexes with PMN. Enveloped HSV can clearly be seen within phagocytic vacuoles and attached to the PMN cytoplasmic membrane. Experiments using HSV incubated either alone or after exposure to nonimmune serum resulted in no visible internalization of virions (data not shown).

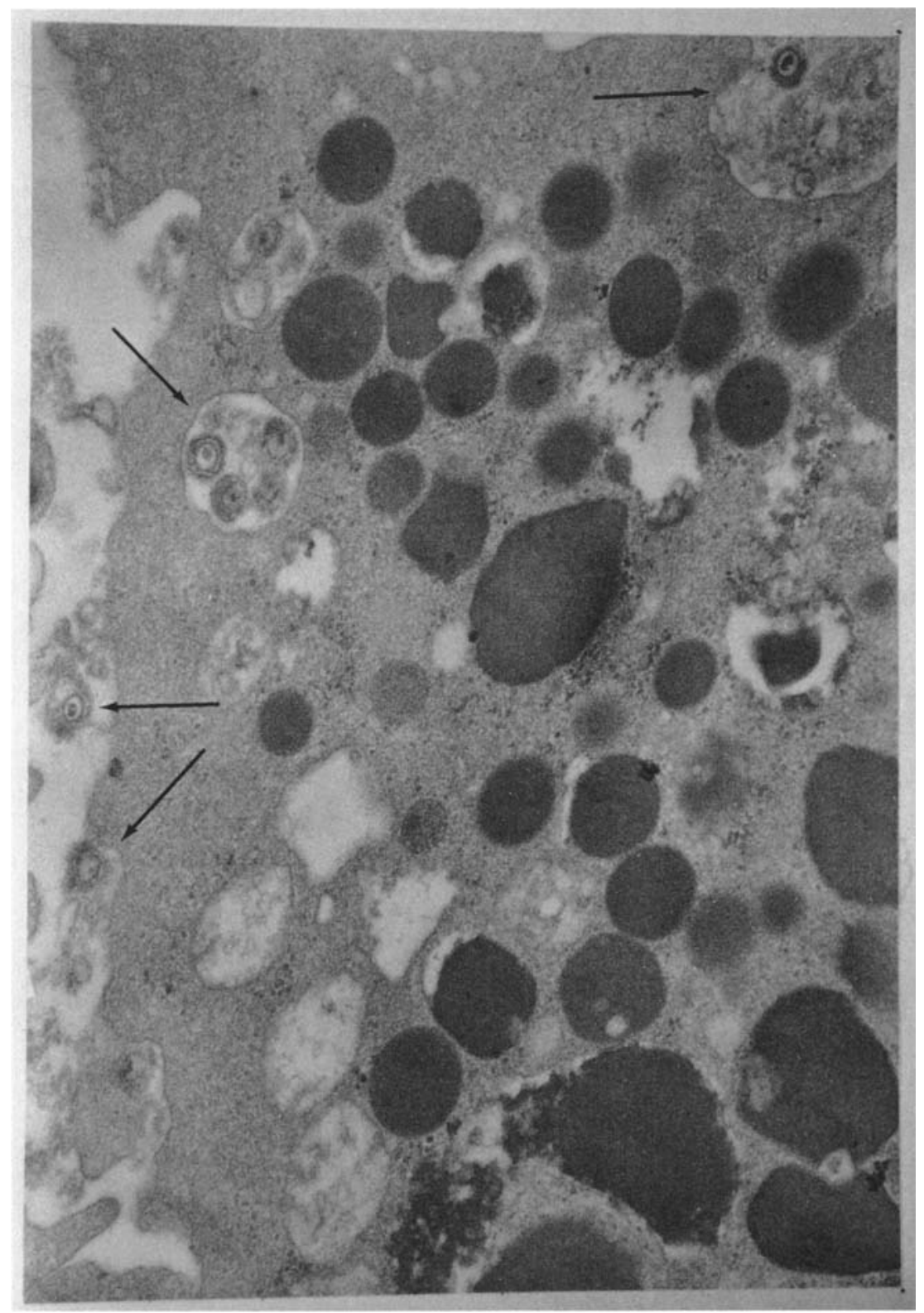

Fig. 3. Internalization of HSV-antibody complexes by PMN. The arrows denote complete enveloped HSV particles that are attached to the cytoplasmic membrane and internalized within the phagocytic vacuoles of rabbit PMN. Photograph was taken $5 \mathrm{~min}$ after addition of virus-antibody complexes to PMN. Magnification, $\times 36,000$. 


\section{DISCUSSION}

Herpetic stromal keratitis causes corneal damage that may result in blindness. At present, it is not clear whether PMN induce, mediate, or contribute to the pathogenesis of the disease in vivo.

Enhancement of HSV virulence may result from the ability of the virus to infect, replicate, and persist in phagocytic cells. Peritoneal exudate macrophages from strains of mice susceptible to HSV infection in vivo have been shown to support the replication of HSV [Brucher et al, 1984]. It has also been shown that HSV [Daniels et al, 1978], rubella [Van Deg Logt, 1980], and dengue-2 [Brandt et al, 1979] viruses are capable of replicating in human monocytes and macrophages. Our laboratory has reported HSV permissiveness following mitogenic stimulation of human lymphocytes [Plaeger-Marshall and Smith, 1978]. In addition, we have demonstrated limited permissiveness of rabbit macrophages to HSV infection [Plaeger-Marshall et al, 1981]. Rabbit monocytes, on the other hand, showed no detectable interaction with virus. In addition to in vitro studies, fluorescent antibody probes have suggested the presence of HSV or HSV antigens within PMN from infiltrates associated with herpetic keratitis [Meyers and Pettit, 1973; Meyers-Elliot et al, 1980; Meyers-Elliot and Chitjian, 1981].

In the present study of HSV-PMN interactions, no replication or adsorption of HSV to PMN was observed. Regarding replication, no increase in virus titer was seen in PMN exposed to HSV. Samples of PMN taken 24-48 hr after exposure to HSV and examined by electron microscopy showed no evidence of complete virions or abortive infection. Binding experiments using PMN mixed with HSV at two MOI's revealed no measurable adsorption, whereas Vero cell controls gave positive binding results under the same conditions. The data presented suggest that rabbit PMN do not recognize HSV by itself, supporting results from studies in this laboratory using chemiluminescence as an assay system [Bingham et al, 1985]. Explanations for PMN nonpermissiveness could be the phagocyte's lack of receptors, short life span, and limited capacity for protein synthesis, all of which my reflect differences in degrees of cellular maturation and differentiation.

It has been well established that PMN ingest and kill bacteria and fungi [Hilger and Danley, 1980; Klebanoff, 1975; Schuit, 1979]. In antiviral defense, PMN are presumed to be active in the clearance of virus-antibody complexes through phagocytosis following recognition by receptors that bind to antibody and complement [Allison, 1974]. Opsonins, such as IgG, interact with the material to be phagocytized, adding a host protein coating that facilitates internalization via the PMN Fc receptor [Eden et al, 1973; Phillips-Quagliata et al, 1969; Theofilopoulos et al, 1974; Wiggins and Cochrane, 1981].

A variety of techniques have been employed to quantitate phagocytosis by PMN. Some methods determine the number of particles removed from the culture medium; others count the number of particles that appear within phagocytes. The uptake of radioactive protein from the suspending medium is another approach to measuring phagocytosis [Chang, 1969]. Using this last approach, Ward and Zvaifler [1973] described a method for the quantitative measurement of phagocytosis by neutrophils using radiolabeled immune complexes. Because of particle size, virus uptake by cells cannot be visually assessed by light microscopy. Therefore, the ability to assay phagocytosis with labeled immune complexes becomes a particularly useful tool when studying the interactions between PMN and viruses. 
In our current study using radiolabeled complexes, we have demonstrated that HSV-antibody complexes bind to PMN. We employed complexes containing either ${ }^{125} \mathrm{I}-\mathrm{HSV},{ }^{35} \mathrm{~S}-\mathrm{HSV}$, or ${ }^{125} \mathrm{I}-\mathrm{IgG}$ and obtained similar patterns of response, thus minimizing the chance that the results observed were an artifact of assay conditions. Increased binding occurred using HSV labeled externally with ${ }^{125}$ Iodine or metabolically with ${ }^{35} \mathrm{~S}$-methionine for the formation of antigen-antibody complexes. When radiolabeled antibody $\left({ }^{125} \mathrm{I}-\mathrm{IgG}\right.$ anti-HSV) was combined with virus in immune complexes, there was a dramatic increase in the binding activity to PMN in contrast to the low activity produced by unaggregated ${ }^{125}$ Iodine labeled HSV-IgG controls. In an unrelated study, using similar procedures, Shinomaya and Koyama [1976] found that ${ }^{125} \mathrm{I}$-IgG alone bound minimally to guinea pig macrophages whereas ${ }^{125} \mathrm{I}-\mathrm{IgG}$ combined with hapten was rapidly bound and internalized.

The addition of complement to virus-antibody complexes is presumed to enhance neutralization and immune clearance through enlargement of viral aggregates. Studies have shown that immune complexes containing complement bind to phagocytes with greater affinity than those without complement [Kijlstra et al, 1979; Mantovani et al, 1972; Van Snick and Masson, 1978]. Our data support the concept that complement increases binding of immune complexes to PMN. The addition of active complement to radiolabeled complexes was found to increase activity associated with PMN by as much as $25 \%$.

The data presented clearly demonstrate that PMN bind HSV-antibody complexes and that the binding activity increases with the addition of complement. To determine whether ingestion as well as adsorption of immune complexes occurs, we employed electron microscopy. This approach resulted in direct visualization of internalized HSV-antibody complexes. Enveloped virions were observed both within phagocytic vacuoles and adherent to the PMN cytoplasmic membrane.

In the initial stages of acute inflammation large numbers of PMN are recruited to destroy and remove the inflammatory stimuli via phagocytosis [Issekutz et al, 1981]. The presence of PMN in the corneal stroma during HSV keratitis can be explained by the liberation of proteases from damaged cells, the activation of the complement cascade by antigen-antibody complexes, the release of leukotactic factors by virus-sensitized lymphocytes, and the chemotactic properties of collagenase in the cornea [Meyers and Pettit, 1974].

Gradually, macrophages accumulate at the same locations for further removal of inflammatory stimuli. Macrophages also initiate tissue repair and immunological responses such as antigen presentation to T lymphocytes. Phagocytic cells at the sites of inflammation bind or ingest immune complexes formed during the course of the disease. Occasionally the removal of such complexes is not efficiently achieved resulting in the subsequent synthesis and release of more inflammatory mediators by PMN and macrophages [Davies and Bonney, 1981].

The pathogenesis of herpetic stromal keratitis remains unclear. It is not fully understood how much of the disease process is due to viral replication and how much is due to the immune response to viral antigens. Our observations that PMN are capable of binding and ingesting HSV-antibody complexes suggest that PMN play a beneficial role in the clearance of virus during herpetic keratitis.

Previous reports [Dawson and Togni, 1976; Pettit and Meyers-Elliot, 1973] have suggested a major role for specifically sensitized lymphocytes in chronic recurrent corneal inflammation. Our data do not exclude such a possibility. It is clear that 
a combination of inflammatory cells are active during the course of herpetic keratitis and that a complete understanding of their interrelationships and mechanisms involved in immune destruction will require further investigation.

\section{ACKNOWLEDGMENTS}

This work was supported by Public Health Service grant EY05105 from the National Eye Institute.

\section{REFERENCES}

Allison AC (1974): Interaction of antibody, complement, and various cell types in immunity against viruses and pyogenic bacteria. Transplantation Review 19:3-55.

Bingham EL, Fenger TW, Sugar A, Smith JW (1985): Dependence on antibody for induction of chemiluminescence in polymorphonuclear leukocytes by herpes simplex virus. Investigative Ophthalmology and Visual Science 26:1236-1243.

Boyum A (1968): Isolation of mononuclear cells and granulocytes from human blood. Scandinavian Journal of Clinical Laboratory Investigation 21:77-89.

Brandt WE, McCown JM, Top FH, Bancroft WH, Russell PK (1979): Effect of passage history on dengue-2 virus replication in subpopulations of human leukocytes. Infection and Immunity 26:534-541.

Brucher J, Domke I, Schroder CH, Kirchner H (1984): Experimental infection of inbred mice with herpes simplex virus. Archives of Virology 82:83-93.

Chang Y (1969): Studies on phagocytosis. I. Uptake of radioiodinated $\left({ }^{131} \mathrm{I}\right)$ human serum albumin as a measure of the degree of phagocytosis in vitro. Experimental Cell Research 54:42-48.

Daniels CA, Kleinerman ES, Snyderman R (1978): Abortive and productive infections of human mononuclear phagocytes by type 1 herpes simplex virus. American Journal of Pathology 91: 119-136.

Davies P, Bonney RJ (1981): Some basic mechanisms of inflammatory responses. In Suran A, Gery I, Nussenblatt RB (eds): "Immunology of the Eye; Workshop III." Arlington, VA: Information Retrieval Inc., pp 273-290.

Dawson CR, Togni B (1976): Herpes simplex eye infections: Clinical manifestations, pathogenesis and management. Survey of Ophthalmology 21:121-135.

Eberle R, Courtney RJ (1980): Preparation and characterization of specific antisera to individual antigens comprising the major glycoprotein region of herpes simplex virus type 1. Journal of Virology 35:902-917.

Eden A, Bianco C, Nussenzweig V (1973): Mechanisms of binding soluble immune complexes to lymphocytes. Cellular Immunology 7:459-473.

Faden H, Hong JJ, Ogra PL (1983): Activation of oxidative and arachidonic acid metabolism in neutrophils by respiratory syncytial virus antibody complexes: Possible role in disease. Journal of Infectious Disease 148:110-116.

Feigin RD, Shakelford PG (1973): Value of repeat lumbar puncture in differential diagnosis of meningitis. New England Journal of Medicine 289:571-574.

Fenger TW, Smith JW, Howe C (1978): Analysis of immunoprecipitated surface glycoproteins in measles virions and in membranes of infected cells. Journal of Virology 28:292-299.

Garvey JS, Cremer NS, Sussdorf DH (eds) (1977): Ammonium sulfate precipitation. In "Methods in Immunology." Reading, MA: WA Benjamin Inc., pp 218-219.

Garvey JS, Cremer NS, Sussdorf DH (eds) (1977): DEAE cellulose chromatography. In "Methods in Immunology." Reading, MA: WA Benjamin Inc., pp 222-226.

Hilger AE, Danley DL (1980): Alteration of polymorphonuclear leukocyte activity by viable Candida albicans. Infection and Immunity 27:714-720.

Irvine AR, Kimura SJ (1967): Experimental stromal herpes simplex keratitis in rabbits. Archives of Ophthalmology 78:654-663.

Issekutz TB, Issekutz AC, Movat HZ (1981): The in-vitro quantitation and kinetics of monocyte migration into acute inflammatory tissue. American Journal of Pathology 103:47-55. 
Kaul TN, Faden H, Ogra PL (1981): Effect of respiratory syncytial virus and virus-antibody complexes on the oxidative metabolism of human neutrophils. Infection and Immunity 32:649-654.

Kijlstra A, Vanes LA, Daha MR (1979): The role of complement in the binding and degradation of immunoglobulin aggregates by macrophages. Journal of Immunology 123:2488-2493.

Klebanoff SJ (1975): Antimicrobial systems of the polymorphonuclear leukocyte. In Dayton DH (ed): "The Phagocytic Cell in Host Resistance." New York: Raven Press, pp 45-59.

Kozel TR, McGaw TG (1979): Opsonization of Cryptococcus neoformans by human IgG: Role of IgG in phagocytosis by macrophages. Infection and Immunity 25:255-261.

Mantovani B, Rabinovitch M, Nussenzweig V (1972): Phagocytosis on immune complexes by macrophages, different roles for the macrophage receptor sites for complement and IgG. Journal of Experimental Medicine 135:780-792.

Marchalonis JJ (1969): An enzymatic method for trace iodination of immunoglobulins and other proteins. Biochemistry Journal 113:299-305.

McConahey PJ, Dixon FJ (1966): A method of trace iodination of proteins for immunologic studies. International Archives of Allergy 24:185-189.

Metcalf JF, McNeill JI, Kaufman HE (1976): Experimental disciform edema and necrotizing keratitis in the rabbit. Investigative Ophthalmology 15:979-985.

Metcalf JF, Reichert RW (1979): Histological and electron microscopic studies of experimental herpetic keratitis in the rabbit. Investigative Ophthalmology 18:1123-1138.

Meyers RL, Pettit TH (1973): The pathogenesis of corneal inflammation due to herpes simplex virus. I. Corneal hypersensitivity in the rabbit. Journal of Immunology 111:1031-1042.

Meyers RL, Pettit TH (1974): Chemotaxis of polymorphonuclear leukocytes in corneal inflammation: Tissue injury in herpes virus infection. Investigative Ophthalmology 13:187-197.

Meyers-Elliot RH, Pettit TH, Maxwell WA (1980): Viral antigens in the immune ring of herpes simplex stromal keratitis. American Journal of Ophthalmology 89:897-904.

Meyers-Elliot RH, Chitjian PA (1981): Immunopathogenesis of corneal inflammation in herpes simplex stromal keratitis: Role of the polymorphonuclear leukocyte. Investigative Ophthalmology and Visual Science 20:784-798.

Meyers-Elliot RH, Chitjian PA, Dethlefs BA (1983): Experimental herpes virus keratitis in the rabbit: Topical versus intrastromal infection routes. Ophthalmic Research 15:240-256.

Notkins AL, Mergenhagen S, Howard R (1970): Effects of virus infections on the functions of the immune response. Annual Review of Microbiology 24:525-538.

Phillips-Quagliata JM, Levine BB, Uhr JW (1969): Studies on the mechanisms of binding immune complexes to phagocytes. Nature 222:1290-1291.

Plaeger-Marshall S, Smith JW (1978): Experimental infection of subpopulations of human peripheral blood leuckocytes by herpes simplex virus. Proceedings of the Society for Experimental Biology and Medicine 158:263-268.

Plaeger-Marshall S, Wilson LA, Smith JW (1981): Permissiveness of rabbit monocytes and macrophages for herpes simplex virus type 1 . Infection and Immunity 35:151-156.

Powell KL, Watson DH (1975): Some structural antigens of herpes simplex virus. Journal of General Virology 29:167-178.

Schuit K (1979): Phagocytosis and intracellular killing of pathogenic yeasts by human monocytes and neutrophils. Infection and Immunity 24:932-938.

Sedlacek HH (1980): Pathophysiological aspects of immune complex disease. Klinische Wochenschrift 58:593-605.

Shinomiya T, Koyama J (1976): In vitro uptake and digestion of immune complexes containing guinea pig IgG1 and IgG2 antibodies by macrophages. Immunology 30:267-275.

Smith DL, Rommel F (1977): A rapid micro method for the simultaneous determination of phagocytemicrobicidal activity of human peripheral blood leukocytes in vitro. Journal of Immunological Methods 17:241-247.

Smith JW, Torres JE, Holmquist ND (1979): Association of herpes simplex virus (HSV) with cervical cancer by lymphocyte reactivity with HSV-1 and HSV-2 antigens. American Journal of Epidemiology 110:141-147.

Stevens DA, Ferrington RA, Jordan GW, Merigan TC (1975): Cellular events in zoster vesicles: Relation to clinical course and immune parameters. Journal of Infectious Diseases 131:509-514.

Theofilopoulos AN, Dixon FJ, Boksich VA (1974): Binding of soluble immune complexes to human lymphoblastoid cells. I. Characterization of the receptors for IgG, Fc, and complement and description of the binding mechanisms. Journal of Experimental Medicine 140:877-894. 
Theofilopoulos AN, Dixon FJ (1979): The biology and detection of immune complexes. Advances in Immunology 28:89-220.

Van Deg Logt JTM, Van Loon AM, Van Der Veen J (1980): Replication of rubella virus in human mononuclear blood cells. Infection and Immunity 27:309-314.

Van Snick J, Masson PL (1978): The effect of complement on the ingestion of soluble antigen-antibody complexes and IgM aggregates by mouse peritoneal macrophages. Journal of Experimental Medicine 148:903-914.

Wander AH, Centifanto YM, Kaufman HE (1980): Strain specificity of clinical isolates of herpes simplex virus. Archives of Ophthalmology 98:1458-1461.

Ward PA, Zvaifler NJ (1973): Quantitative phagocytosis by neutrophils. I. A new method with immune complexes. Journal of Immunology 111:1771-1776.

Wiggins RC, Cochrane GC (1981) Immune complex mediated biologic effects. New England Journal of Medicine 304:518-520. 